\title{
PROSPECTS FOR GULF OF MEXICO ENVIRONMENTAL RECOVERY AND RESTORATION
}

By Denis A. Wiesenburg, Bob Shipp, F. Joel Fodrie, Sean Powers, Julien Lartigue, Kelly M. Darnell, Melissa M. Baustian, Cam Ngo, John F. Valentine, and Kateryna Wowk

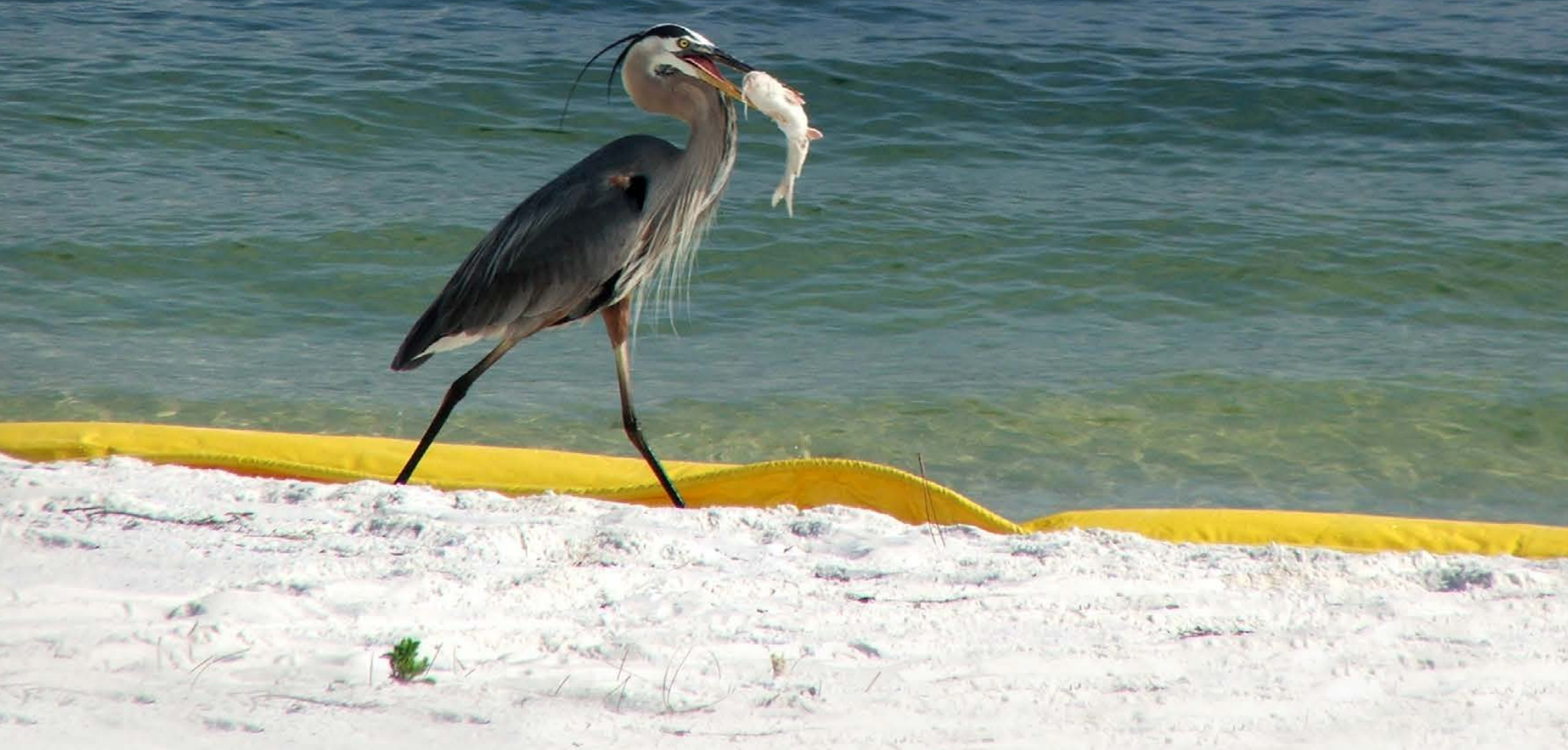


ABSTRACT. Previous oil spills provide clear evidence that ecosystem restoration efforts are challenging, and recovery can take decades. Similar to the Ixtoc 1 well blowout in 1979, the Deepwater Horizon (DWH) oil spill was enormous both in volume of oil spilled and duration, resulting in environmental impacts from the deep ocean to the Gulf of Mexico coastline. Data collected during the National Resource Damage Assessment showed significant damage to coastal areas (especially marshes), marine organisms, and deep-sea habitat. Previous spills have shown that disparate regions recover at different rates, with especially long-term effects in salt marshes and deepsea habitat. Environmental recovery and restoration in the northern Gulf of Mexico are dependent upon fundamental knowledge of ecosystem processes in the region. PostDWH research data provide a starting point for better understanding baselines and ecosystem processes. It is imperative to use the best science available to fully understand DWH environmental impacts and determine the appropriate means to ameliorate those impacts through restoration. Filling data gaps will be necessary to make better restoration decisions, and establishing new baselines will require long-term studies. Future research, especially via NOAA's RESTORE Science Program and the state-based Centers of Excellence, should provide a path to understanding the potential for restoration and recovery of this vital marine ecosystem.

\section{INTRODUCTION}

When a coastal ecosystem is damaged by oil, the system can recover gradually over time without intervention, although the new state of the ecosystem may not be equal to that before the damage. Generally, mitigation efforts that are undertaken to minimize the amount of oil reaching the coast include oil collection by skimmers, burning of the oil at sea, and the application of dispersants to reduce the oil to smaller droplets, thereby increasing oil surface area and allowing natural processes to more fully and quickly interact with the oil. When oil reaches the shore and causes damage to the coastal ecosystem, restoration efforts are often used to speed the recovery of the ecosystem. Mitigation efforts following the Deepwater Horizon (DWH) oil spill included those listed above as well as release of freshwater from the Mississippi River to hopefully keep the oil offshore, and even the building of berms to protect coastal areas. Restoration efforts included mechanically sifting the oil from beaches, cleaning marine animals, and eventually planting new marsh grasses to speed recovery. This article considers the prospects for environmental recovery based on what we know from previous oil spills and from the data on the coastal ecosystem of the Gulf of Mexico collected since the DWH oil spill.

\section{LESSONS LEARNED FROM EARLIER SPILLS}

The Ixtoc 1 oil blowout in the southern Gulf of Mexico in June 1979 had many similarities to the DWH oil spill. It was a well blowout that released massive amounts of crude oil ( $>3.4$ million barrels) into a tropical marine environment; the well leaked for over nine months and reached all the way into Texas waters. Soto et al. (2014) reviewed the environmental legacy of the Ixtoc 1 blowout. Like DWH, the impacts of the Ixtoc 1 spill were initially mitigated by physical and chemical processes and the region's local hydrological and biological conditions. However, even today, Ixtoc 1 oil residues are measurable, especially in the sediments and on shore, and some scientists suggest that the collapse of important commercial shrimp species stocks are attributable to the spill, though there is disagreement about this. Soto et al. (2014) note that the lack of adequate pre-spill information precluded a robust assessment of the Ixtoc 1 spill's damage to the ecosystem. Intense research was conducted while the oil flowed; however, when Ixtoc 1 oil stopped flowing, many research efforts funded by US agencies ceased. As a result, the total extent of environmental damage from the Ixtoc 1 oil spill is not fully understood, while the official position of the Mexican federal agencies is that no environmental damage was caused by the Ixtoc 1 blowout (Soto et al., 2014).

Before DWH, the largest oil spill in US waters came from the Exxon Valdez tanker accident in March 1989, where 257,000 barrels of North Slope crude oil was released into the cold, pristine waters of Prince William Sound, Alaska. The oil eventually affected $2,100 \mathrm{~km}$ of coastline, of which $320 \mathrm{~km}$ were heavily oiled. During the response, the carcasses of more than 35,000 birds and 1,000 sea otters were found, the herring fishery eventually collapsed, and two pods of killer whales have yet to recover. Mitigation techniques ranged from booms to keep the oil out of rivers and away from shorelines where salmon spawned to hot water cleaning of rocky beaches. The hot water made for great television, but it was eventually abandoned when it was realized that small coastal organisms were killed by the hot water. In the long term, fauna associated with hot water cleaned beaches recovered more slowly than those associated with beaches that were either left alone or treated by spraying nutrients on the rocky beach (Houghton, 1991). Peterson et al. (2003) concluded that because of persistence of oil in the ecosystem, the longterm population impacts are likely more important than the acute species mortality immediately following the spill. Even today, small amounts of oil can be found under rocks on the beaches of Prince William Sound (Nixon and Michel, 2018), and some species have not fully recovered. Esler et al. (2018) examined timelines for wildlife population recovery and found that for some species, the oil effects that persisted for decades had a large influence on population dynam- 
ics. These chronic effects may have been more harmful than the acute toxic effects of the oil itself. Unlike for Ixtoc 1, a legacy of post-Exxon Valdez research is available, as long-term research funding was made available through federal agencies and the Exxon Valdez Oil Spill Trustee Council; the most recent effort is the Gulf Watch Alaska Program initiated in 2012 with a 20-year lifetime (Aderhold et al., 2018). Another outcome of the Exxon Valdez accident was passage of the Oil Pollution Act of 1990 that established how response to future oil spills would be managed and required the responsible parties to pay for the cleanup and restoration efforts.

\section{DEEPWATER HORIZON IMPACTS}

Detailed examination of impacts on various components of northern Gulf of Mexico habitats is beyond the scope of this paper. However, the following sections include a brief review of the status of several of the more prominent habitats and species impacted by the DWH oil spill, including wetlands and mortality of fish larvae, invertebrates, sea turtles, and cetaceans. (Please see other articles in this issue for further information.) In addition, we present a more detailed review of impacts on wetland fisheries and oyster restoration.

In accordance with the Oil Pollution Act of 1990 (OPA), an assessment of damage to the environment was conducted by scientists from NOAA and their contractors as part of the OPA-required National Resource Damage Assessment (NRDA; DHNRDAT, 2016).

In general, coastal habitats were fairly well buffered from the impact of the DWH oil spill, except for those of Louisiana. Much of that impact is documented elsewhere in this issue, but in general, NRDA-identified damages that relate to the coastal zone include the following.

The DWH oil spill resulted in the oiling of 2,113 km of coastline (Nixon et al., 2016), including $763 \mathrm{~km}$ of coastal marsh shoreline with $135 \mathrm{~km}$ heavily oiled, mainly in Louisiana (Michel, et al., 2013). Many acres of wetlands were damaged, and depending on the degree of oiling, it was estimated that marsh recovery would take from two to four years for intensely treated areas and eight years for those that were untreated (Michel and Rutherford, 2014; DHNRDAT, 2016). Some residual oil is still found in the Louisiana coastal sediment. Based on the degradation rates from oil spilled in Prince William Sound, continued degradation will be extremely slow, and oil will continue to surface through erosion for the next decade or more (Lindeberg et al., 2018). From previous studies, we also learned that marsh restoration can be enhanced by the planting of Spartina in salt marshes and Juncus in the freshwater marshes (Bergen et al., 2000; Mendelssohn et al., 2012). Some efforts to restore marshes are necessary, as Zengel et al. (2015) show that in the Louisiana marsh areas not treated after DWH, most ecological parameters had not improved two years after the spill. It follows that the benthic infauna will recover fairly quickly once native vegetation is restored.

The number of fish killed was estimated during the NRDA process using biological data from NRDA-specific field studies, historical collections, NRDA toxicity testing studies, and published literature. Both direct kill and forgone production of fish and invertebrates exposed to DWH oil in the surface slick and the subsurface mixed zone were calculated. The exposure resulted in the death of between 2 trillion and 5 trillion fish larvae and between 37 trillion and 68 trillion planktonic invertebrates (DHNRDAT, 2016). Of these totals, 0.4-1 billion larval fish and 2-6 trillion invertebrates were killed in estuarine surface waters. The NRDA process also quantified the direct kill of fish and invertebrates exposed to DWH oil both in the rising cone of oil and in the deepwater plumes, as well as foregone production for a critical subset of these species. The exposure resulted in the death of between 86 million and
26 billion fish larvae and between 10 million and 7 billion planktonic invertebrates (DHNRDAT, 2016).

In general, the fish communities of the coastal Gulf of Mexico were found not to suffer long-term damage from the DWH oil spill (see below). Those communities have now recovered, and there has so far been no evidence of long-term sublethal impacts, showing the resilience of coastal fish communities (Patterson et al., 2015). As with the benthic community, once the habitat is restored, the organisms will follow.

The NRDA Trustees estimated that between 4,900 and 7,600 large juvenile and adult sea turtles and between 55,000 and 160,000 small juvenile sea turtles were killed by exposure to DWH oil. The Trustees also estimated that nearly 35,000 hatchling sea turtles were injured by response activities associated with the DWH oil spill. Likely, the most problematic impacts in the coastal zone were to higher-level vertebrates. Organisms such as birds, turtles, and marine mammals were unable to avoid the oil as it spread near the shore. Multiple recovery efforts were attempted during the spill to clean and release contaminated birds and turtles. Unfortunately, that was not possible with marine mammals. Mortalities of dolphins and turtles were documented during and immediately following the spill. Dolphin data collection funded during NRDA and continued by the Gulf of Mexico Research Initiative (GoMRI) documented dolphin fetal mortality, respiratory stress, and challenged immune responses. A variety of innovative studies conducted between 2010 and 2015 under the NRDA process documented that marine mammals experienced severe negative effects such as lung disease, reduced reproduction, and elevated death rates (see Barratclough et al., 2019). Unfortunately, restoration is not possible for this group of organisms, and it will simply take a long time for recovery to work through the system due to low reproductive success after the oil spill (Lane et al., 2015). 


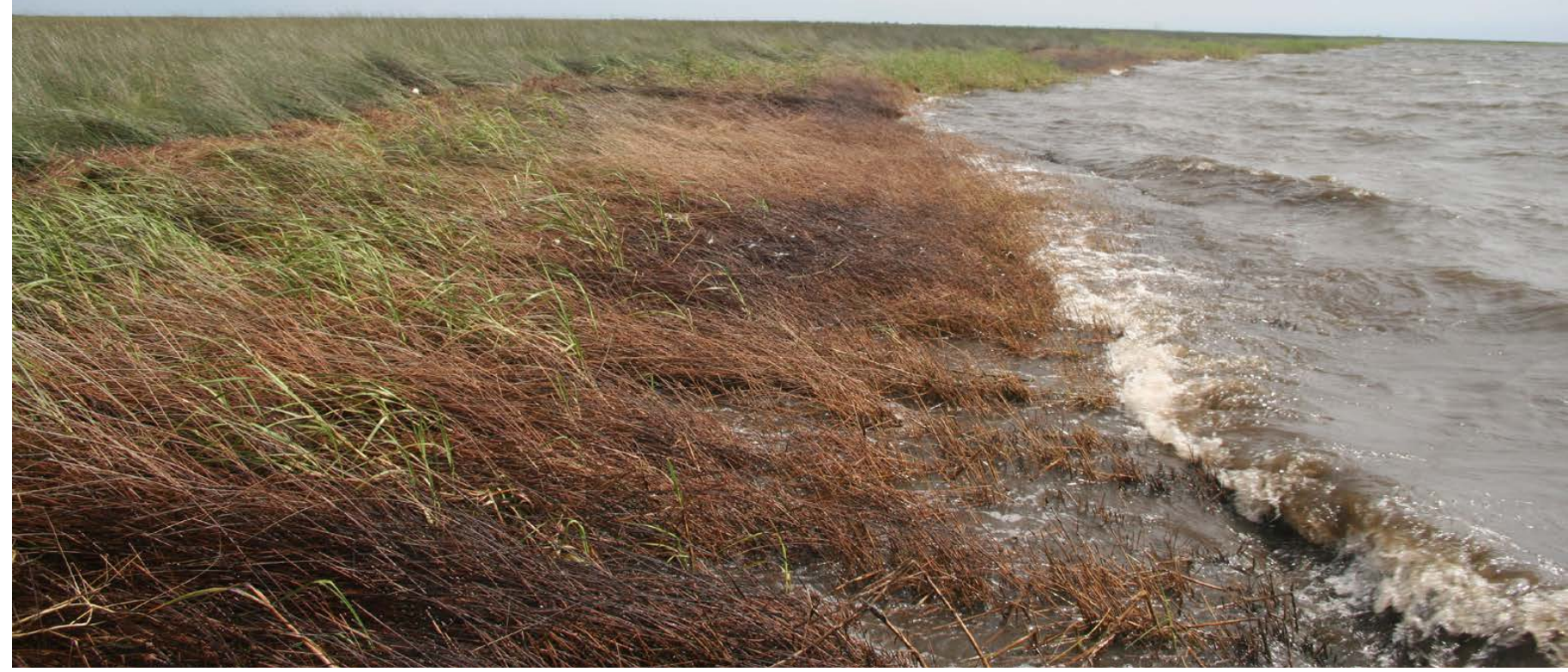

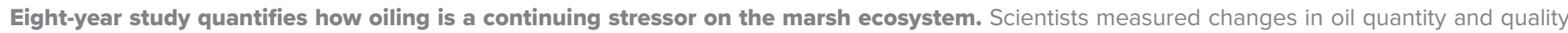

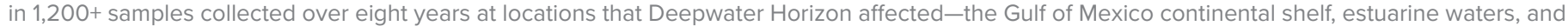

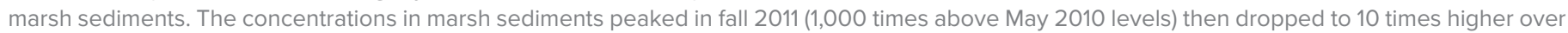

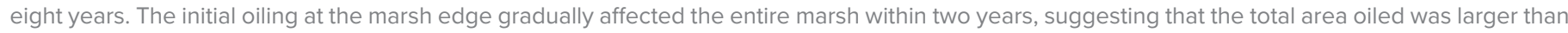

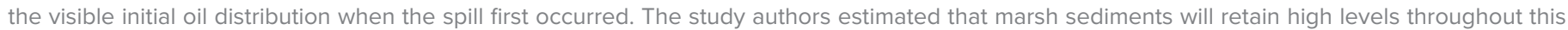
century. Photo credit: R. Eugene Turner, Louisiana State University

\section{ESTUARINE FISHERIES}

The 2010 DWH oiling disaster challenged the integrity and long-term future of the Gulf of Mexico ecosystem at unprecedented scales. It led to immediate, but temporary, shutdown of fisheries harvesting and prompted serious concerns that there might be catastrophic injury to Gulf fishes and fisheries. However, nekton sampling at multiple, paired oiled and unoiled sites during 20122013 in Barataria and Terrebonne Bays, Louisiana, among the most heavily oiled salt marshes along the northern Gulf following the spill (DHNRDAT, 2016), documented no lasting differences in the densities, sizes, or assemblage structures of seven resident Cyprinodontiformes fishes (including the sentinel species, Gulf killifish, Fundulus grandis; Able et al., 2015). Similarly, catch rates of marsh-resident species, as well as overall community structure, were not different before (2009) versus after (2010-2011) oiling at impacted wetlands in Alabama (Moody et al., 2013). Likewise, settlement of blue crab, Callinectes sapidus, did not change in northern Gulf wetlands following the spill (Grey et al., 2015). Shrimp abundances in oil-impacted Louisiana embayments actually increased in the aftermath of the spill, perhaps due to delayed migration offshore and/or reduced harvest pressure (van der Ham and de Mutsert, 2014).

In addition to these spill-response patterns observed among marsh-associated nekton, similar patterns of stability in fish populations and communities have emerged post DWH in diverse northern Gulf settings such as seagrass-associated fishes (Fodrie and Heck, 2011), estuarine fishes throughout Mississippi Sound (Schaefer et al., 2016), and within the coastal population of Gulf menhaden, Brevoortia patronus, a key forage fish (Short et al., 2017).

The general resilience to unprecedented oiling exhibited by fishes, crabs, and shrimps at population levels has been surprising given what is known about the impacts of hydrocarbons on individuals within these marsh-associated taxa following DWH. In both lab experiments and field collections since 2010, individuals from these same taxa have shown negative responses to both oil constitu- ents (e.g., polyaromatic hydrocarbons) and dispersants used to break down oil slicks. Indeed, a review of peer-reviewed studies demonstrated that in $\sim 99 \%$ of cases (Fodrie et al., 2014), individual marsh-associated fishes exposed to even low concentrations ( 1 ppb) of weathered Macondo oil and/or Corexit dispersants from the DWH oil spill demonstrated negative responses in terms of genomic expression, physiologic performance, morphological defects, and even mortality rate (Whitehead et al., 2012; Dubansky et al., 2013; Kuhl et al., 2013).

Several factors may help reconcile why these individual-level damages do not appear to manifest as losses at the population or community level for marshassociated nekton. In addition to the fishery closures in 2010 that potentially reduced adult mortality and increased recruitment of summer/fall spawning species (Fodrie and Heck, 2011), many fishes, crabs, and shrimps may have relied on their mobility to detect and then evade oiling (Martin, 2017). In many estuaries, the distribution of oil was highly patchy and could have allowed for avoid- 


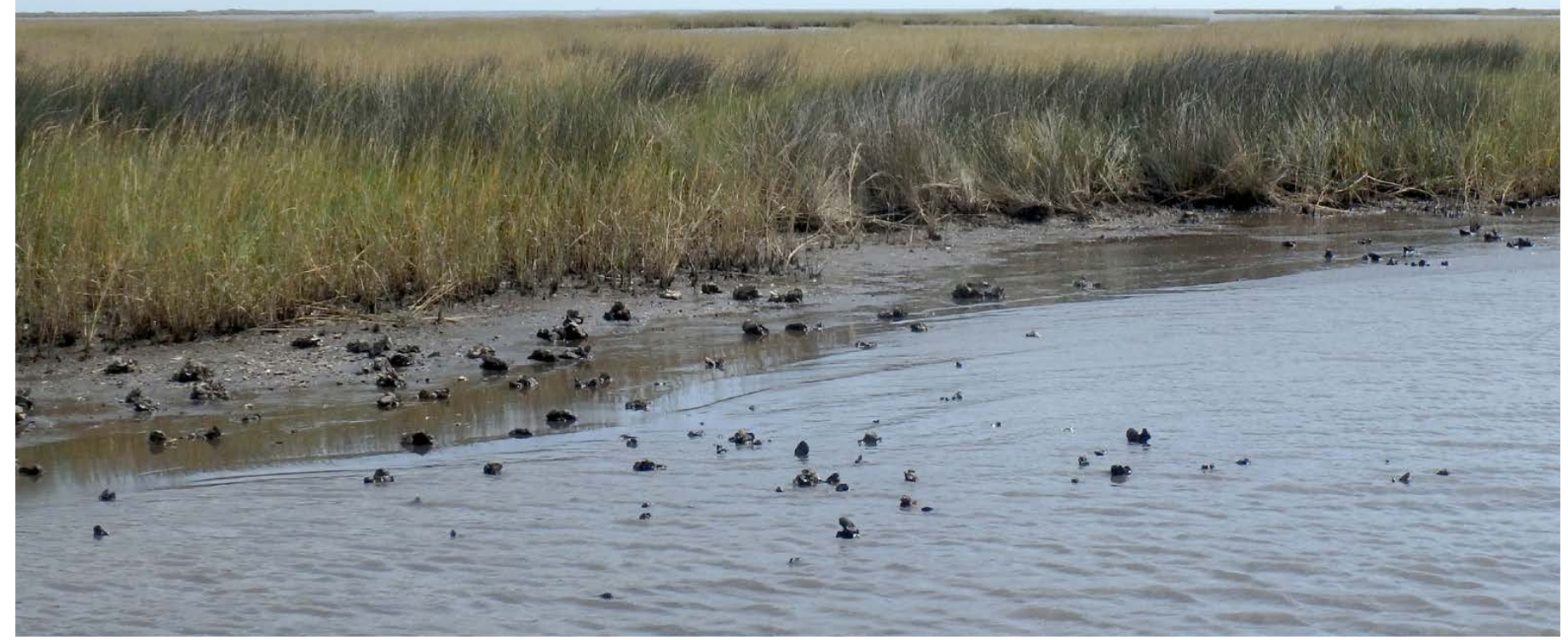

Oyster populations in many areas of the north-central Gulf of Mexico were severely impacted. Researchers concluded impacts on oysters were primarily due to activities associated with response to the DWH oil spill. The summer release of large quantities of freshwater from the Mississippi River through the Caernarvon and Davis Pond diversion structures as the State of Louisiana moved to protect marsh ecosystems from the inflow of oil in 2010 resulted in the loss of 2-3 billion market-sized oysters from subtidal areas of Barataria Bay and Black Bay/Breton Sound estuaries (Grabowski et al., 2017; Powers et al., 2017b). (photo) Louisiana coastal oysters exposed at low tide. Photo credit: Meagan Schrandt

ance behaviors for highly mobile species, despite strong site fidelity at landscape scales (Jensen et al., 2019). Additionally, we know that many marine birds and mammals were impacted by Macondo oil, and reduced numbers of these predators might have also offset oil-related mortality on smaller fishes (Lane et al., 2015; Short et al., 2017). These are only a subset of the possible explanations that can be considered but are ultimately difficult to fully test as causal agents for observed patterns-which reinforces the complexity of ecosystem response(s) to broadscale oiling, as well as defining directions for future research. Additionally, other studies highlight the importance of identifying key taxa in the response of ecosystems to perturbations based on both their sensitivity to stressors (i.e., oiling) and their importance in the overall web of interactions (McCann et al., 2017).

\section{OYSTER RESTORATION AND RECOVERY}

Oyster populations in many areas of the north-central Gulf of Mexico were severely impacted, primarily due to activities associated with response to the DWH oil spill. During the injury assessment phase, the DWH NRDA Trustee Council directed significant resources to evaluating the impacts on oyster resources, including support of longer-term monitoring of many oyster habitats. The complexity of assessing the immediate and long-term effects of the DWH spill on oysters cannot be overstated: they were impacted both as direct consequences of oiling and response activities (e.g., freshwater diversion release, shoreline cleanup), and by the interaction of oiling and response activities. In addition, oyster resources in the Gulf region fluctuate naturally because recruitment changes in response to freshwater inflow patterns to estuaries, and because there is a legacy of different harvest regimes.

Studies in the aftermath of the DWH oil spill demonstrated that disturbances resulting from oiling and various response activities can have substantial impacts on oyster resources. The summer release of large quantities of freshwater from the Mississippi River through the Caernarvon and Davis Pond diversion structures as the State of Louisiana moved to protect marsh ecosystems from the inflow of oil in 2010 resulted in the loss of 2-3 billion market-sized oysters from subtidal areas of Barataria Bay and Black Bay/Breton Sound estuaries (Grabowski et al., 2017; Powers et al., 2017b). Mesocosm experiments funded by GoMRI indicated that exposing oysters to short periods of low salinity could help them combat oil contaminant effects; however, this must be balanced by heavy expected mortality resulting from extended periods at very low salinity (Schrandt et al., 2018). Oysters near the shoreline (fringing oyster reefs) suffered injury from direct oiling as well as from oil removal efforts (Powers et al., 2017a). While the magnitude of oysters killed in the nearshore was an order of magnitude less than in subtidal areas (34 million vs. 2-3 billion market-sized oysters), the loss of fringing oysters from the shoreline resulted in increased marsh erosion and additional loss of spawning stock biomass.

The combined effects of massive decreases in oysters in the subtidal and nearshore oyster areas likely contributed to the prolonged recovery seen in follow-up studies that were funded by GoMRI as a result of decreased oyster 
recruitment (from the loss of spawning stock biomass). Recent research demonstrated that the longevity of oyster shell, which is necessary to support high settlement of oysters, is limited because of bioerosion and dissolution processes in the environment (Dunn et al., 2014). Consequently, recovery from natural and anthropogenic disturbances may not be adequate if natural recovery extends beyond the lifetimes of shell resources. In such instances, active restoration will be required to restore the oyster resources of the northern Gulf of Mexico.

\section{INFORMING AND TRACKING GULF OF MEXICO RECOVERY}

To promote the recovery of the Gulf of Mexico region following the DWH oil spill, the US Congress passed the Resources and Ecosystems Sustainability, Tourist Opportunities, and Revived Economies of the Gulf Coast States Act of 2012 (known as the RESTORE Act). This law dedicated $80 \%$ of the Clean Water Act penalties paid by responsible parties in connection with the spill to the Gulf region to promoting ecological and economic recovery activities. Two of the programs established by the Act, the NOAA RESTORE Science Program and the Centers of Excellence Research Grants Program, focus on supporting research, observation, technology, and monitoring in the Gulf of Mexico. Each program is funded by roughly $\$ 138$ million plus a portion of the interest from the penalty payments.

The NOAA RESTORE Science Program's mission considers the longterm sustainability of the Gulf of Mexico ecosystem, including its fish stocks, fish habitat, and fishing industries; its work is funded directly from the trust fund of Clean Water Act penalties established by the RESTORE Act. Working in partnership with the US Fish and Wildlife Service, the Science Program seeks to accomplish two equally important longterm outcomes. One is to improve understanding of the processes and connections within the Gulf of Mexico ecosystem. The other is to apply this inte- grated knowledge of the ecosystem to its sustainable management and restoration (NOAA, 2015). NOAA has laid the foundation to do so by building a program that connects the capacity of the research community to the information needs of resource managers in the Gulf region. By designing its funding opportunities around the needs of resource managers, using a competitive selection process, and working closely with their funded projects, the Science Program is supporting quality research and its application.

The Science Program recognizes the importance of making long-term investments. In the fall of 2019, the Science Program made its first set of long-term awards, which may provide up to 10 years of continuous funding to teams working on long-term trends in living coastal and marine resources in the Gulf of Mexico and the processes that drive them. Such long-term awards have the potential to be transformative by providing sustained funding to promising researcher and resource manager partnerships. To further explore the relationships between trends and processes in the ecosystem and lay the foundation for ecosystem-based management, the Science Program will also support a synthesis initiative that cuts across disciplines and seeks to gain new insights from existing data.

Since its inception, the Science Program has increasingly recognized the importance of investing in research and resource management partnerships. The program has begun to emphasize the use of co-production as one way to generate actionable science. The co-production of science involves iterative collaboration between a researcher and a resource manager in all phases of a research project, and it is often centered around reducing the uncertainties around a specific decision the manager has to make. In addition to conducting competitions to fund co-produced science, the Science Program is also exploring ways to increase the capacity for co-production of science in the Gulf of Mexico region by initiating workshops, seminars, and con- ference sessions.

Working with priorities set by the research and application needs of resource managers, the Science Program continues to seek opportunities to support monitoring and research that can inform restoration decisions and evaluate restoration outcomes as articulated by practitioners. The key to delivering relevant research findings and products is designing and conducting experiments, models, and monitoring networks tailored to the needs of restoration managers. Rigorous science and monitoring are critical, but it will only be utilized if it is delivered at the geographic and temporal scale of the restoration action and its utility is recognized by the resource manager-ideally even before it is produced.

\section{THE CENTERS OF EXCELLENCE RESEARCH GRANTS PROGRAM}

The Centers of Excellence Research Grants Program funds research, science, technology, and monitoring with administrative and civil penalties housed in the RESTORE Act Trust Fund from the DWH oil spill. The Centers of Excellence Program, with a budget of more than $\$ 138$ million, is near the beginning of its 15-year tenure, with at least one Center of Excellence established in each Gulf Coast State. Centers of Excellence are required to focus on at least one of five disciplines in the Gulf of Mexico or Gulf Coast Region: (1) coastal and deltaic sustainability, (2) coastal fisheries and wildlife, (3) offshore energy development, (4) sustainable and resilient growth and economic development, and (5) observation, monitoring, and mapping. All Centers prioritize data discoverability, accessibility, and usability by other researchers over the long term, and most Centers are housing data at the Gulf of Mexico Research Initiative Information and Data Cooperative. Although the Centers are self-directed and operate in support of separate missions, they all follow the same guidelines and regulations stipulated by the US Department of Treasury, as administrator for the Centers 
of Excellence Program, and funds for each Center are required to pass through a designated state entity.

\section{Texas OneGulf Center of Excellence} Texas OneGulf is a consortium of nine top state institutions led by the Harte Research Institute for Gulf of Mexico Studies at Texas A\&M University-Corpus Christi. It has wide-ranging expertise in the environment, the economy, and human health. Texas OneGulf was established in 2015 with a mission to improve understanding of the Gulf of Mexico large marine ecosystem and its effects on human health and well-being for the betterment of both. In its initial years, Texas OneGulf supported seven research projects totaling nearly \$3 million in RESTORE funding to tackle a variety of issues that directly impact Texas, the Gulf of Mexico, and its residents. These projects include establishing disaster research response infrastructure that can be deployed rapidly to assess the impacts of disasters along the Texas coast in real time, using underwater gliders to search the coast for hypoxic dead zones, and helping Texas communities build resilience and recover from Hurricane Harvey. The diversity and interdisciplinary nature of the projects helped OneGulf become a reliable source of information for Texas decision-makers and resource managers working to protect the Gulf and its coastal communities.

\section{RESTORE Act Center of Excellence}

\section{for Louisiana}

The mission of the RESTORE Act Center of Excellence for Louisiana (LA-COE) is to fund research directly relevant to Louisiana's Comprehensive Master Plan for a Sustainable Coast by administering a competitive grants program and coordinating support to ensure that success metrics are tracked and achieved. The Coastal Master Plan is the guiding document for the Coastal Protection and Restoration Authority (CPRA) that was developed using the best available science and engineering to focus efforts and guide the actions needed to sustain
Louisiana's coastal ecosystem, safeguard coastal populations, and protect vital economic and cultural resources. LA-COE is sponsored by CPRA and administered by The Water Institute of the Gulf. LA-COE began in 2014 and has been working with CPRA and various other advisory groups and scientists from The Water Institute of the Gulf to advance the LA-COE mission. In 2017, LA-COE granted universities nearly \$3 million to support 13 research, collaborative, and graduate studentship awards. Research topics ranged from coastal restoration impacts to brown pelican nesting habitat, assessment of adaptive migration for coastal residents, and use of radar-based precipitation data sets for hydrology models.

\section{Mississippi Based RESTORE Act \\ Center of Excellence}

The Mississippi Based RESTORE Act Center of Excellence (MBRACE) is a consortium of Mississippi's four research universities-Jackson State University, Mississippi State University, The University of Mississippi, and The University of Southern Mississippi (USM) - with USM serving as the lead institution. The mission of MBRACE is to seek sound comprehensive scienceand technology-based understanding of the chronic and acute stressors on the dynamic and productive waters and ecosystems of the northern Gulf of Mexico, and to facilitate sustainable use of the Gulf's resources. Since its designation in 2016, MBRACE has dedicated more than $\$ 7$ million to support oyster reef sustainability and water quality in Mississippi coastal waters, prioritizing research and modeling to inform management and restoration activities led by the Mississippi Department of Environmental Quality, the Center of Excellence pass-through entity in Mississippi, and the Mississippi Department of Marine Resources. The close partnership between MBRACE and state resource managers enables the Center to support research that both increases the state of knowledge and addresses critical management needs.

\section{Alabama Center of Excellence}

In the interest of being better prepared to respond to future disasters, the Alabama Center of Excellence (AL COE) will develop and implement a forward-looking competitive grant program that will fund up to 22 research grants and conduct hypothesis-driven, ecosystem-based monitoring focused on the development of data-driven predictions of impacts of future multi-stressors on the coastal and nearshore environments of the north central Gulf of Mexico. Lead scientists will be located at Alabama Marine Environmental Sciences Consortium's 23 member schools, and ecosystem-based monitoring will be led by resident faculty at the Dauphin Island Sea Lab. AL COE will also fund improvements to the Alabama Real-time Coastal Observing System (ARCOS), a core program administered by the Dauphin Island lab. ARCOS collects and disseminates quality-controlled hydrographic and meteorological data to a diverse and large array of stakeholders (e.g., US Coast Guard, National Weather Service, Alabama Department of Public Health) who depend on these data for a range of regulatory, commercial, and recreational activities. Partners in the evaluation of AL COE's work plan will include Mississippi-Alabama Sea Grant and the Mobile Bay National Estuary Program.

\section{Florida RESTORE Act Centers}

\section{of Excellence Program}

In Florida, the RESTORE Act stipulated that the Florida Institute of Oceanography (FIO) serve as the Gulf Coast State Entity, responsible for conducting a competitive grant process to establish Florida's Centers of Excellence rather than serving as the Center of Excellence itself. FIO serves as the program headquarters for the Florida RESTORE Act Centers of Excellence Program (FLRACEP) and is responsible for administering the program's funds and evaluating the performance of each Florida Center of Excellence. Guided by the FLRACEP management team, the program seeks to engage, coordi- 


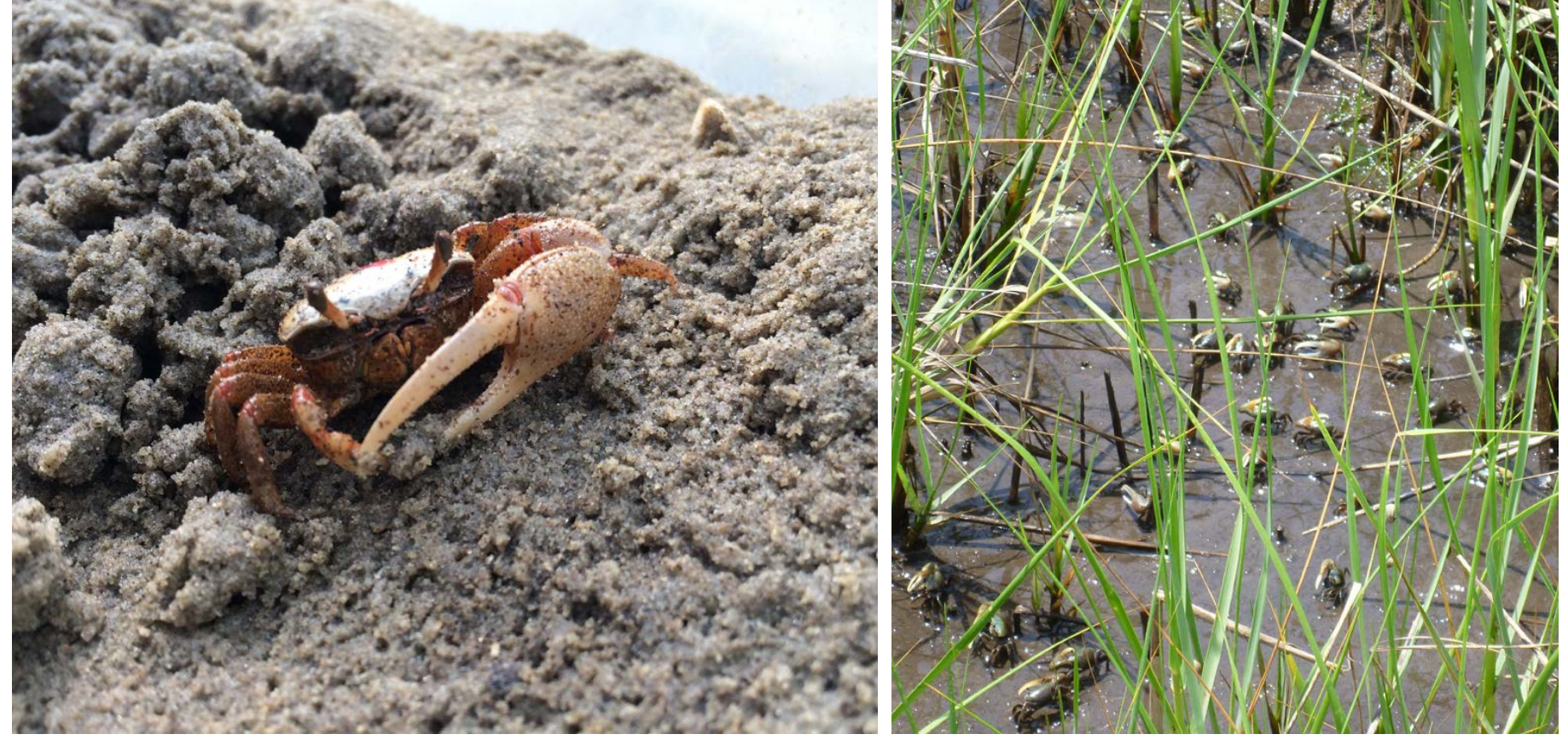

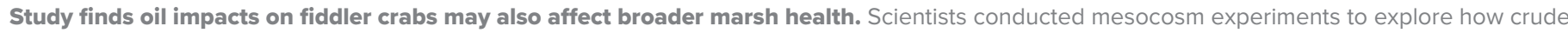

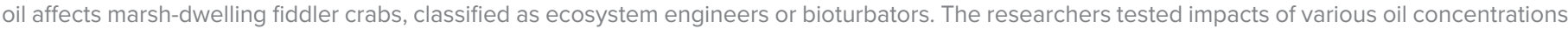

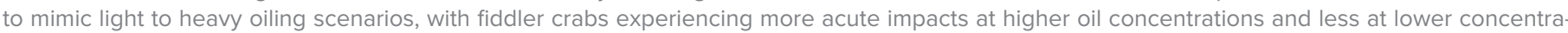
tions. The study results suggest that oil impacts on fiddler crabs may have implications for other species that depend on them for food or ecological

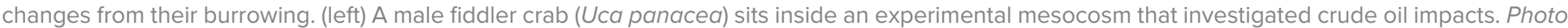
credit: M.E. Franco, University of Louisiana, Lafayette. (right) Fiddler crabs in a marsh. Photo credit: CWC Consortium, LUMCON

oil spill occurred, making comparison of impacts difficult. However, the GoMRI effort has provided many starting points for long-term studies. In addition, the RESTORE Science Program and the 30-year National Academies of Sciences Gulf Research Program (NRC, 2014) will enable researchers to continue assessments well into the future. Also, the Centers of Excellence Research Grants Program is designed to extend for many years, providing support for scientists to focus on regionally important long-term investigations.

A "new normal" for habitats and impacted ecosystems is often referenced as a possibility. Again, its determination requires extended studies. With the passage of time, as recovery progresses, and anthropogenic influence is included, a return to the previous, or some new, "normal" can be ascertained. @

\section{REFERENCES}

Able, K.W., P.C. López-Duarte, F.J. Fodrie, O.P. Jensen, C.W. Martin, B.J. Roberts, J. Valenti, K. O'Connor, and S.C. Halbert. 2015. Fish assemblages in Louisiana salt marshes: Effects of the Macondo oil spill. Estuaries and Coasts 38(5):1,385-1,398, https://doi.org/10.1007/s12237-014-9890-6.
Aderhold, D.G.R., K. Holderied, M.R. Lindeberg, and W.S. Pegau. 2018. Spatial and temporal ecological variability in the northern Gulf of Alaska: What have we learned since the Exxon Valdez oil spill? Deep Sea Research Part // 147:3-8, https://doi.org/ 10.1016/j.dsr2.2017.11.015.

Barratclough, A., R.S. Wells, L.H. Schwacke, T.K. Rowles, F.M. Gomez, D.A. Fauquier, J.C. Sweeney, F.I. Townsend, L.J. Hansen, E.S. Zolman, and others. 2019. Health assessments of common bottlenose dolphins (Tursiops truncatus): Past, present, and potential conservation applications. Frontiers in Veterinary Science 6:444 https://doi.org/10.3389/fvets.2019.00444.

Bergen, A., C. Alderson, R. Bergfors, C. Aquila, and M.A. Jatsil. 2000. Restoration of a Spartina alterniflora salt marsh following a fuel oil spill, New York City, NY. Wetlands Ecology and Management 8:185-195, https://doi.org/ 10.1023/A:1008496519697.

DHNRDAT (Deepwater Horizon Natural Resource Damage Assessment Trustees). 2016. Deepwater Horizon Oil Spill: Final Programmatic Damage Assessment and Restoration Plan and Final Programmatic Environmental Impact Statement, http://www.gulfspillrestoration.noaa.gov/ estoration-planning/gulf-plan.

Dubansky, B., A. Whitehead, J.T. Miller, C.D. Rice, and F. Galvez. 2013. Multitissue molecular, genomic, and developmental effects of the Deepwater Horizon oil spill on resident Gulf killifish (Fundulus grandis). Environmental Science \& Technology 47:5,074-5,082, https://doi.org/10.1021/ es400458p.

Dunn, R.P., D.B. Eggleston, and N. Lindquist. 2014. Oyster-sponge interactions and bioerosion of reef-building substrate materials: Implications for oyster restoration. Journal of Shellfish Research 33:727-738, https://doi.org/ 10.2983/035.033.0307.

Esler, D., B.E. Ballachey, C. Matkin, D. Cushing, R. Kaler, J. Bodkin, D. Monson, G. Esslinger, and K. Kloecker. 2018. Timelines and mecha- nisms of wildlife population recovery following the Exxon Valdez oil spill. Deep-Sea Research Part I/ 147:36-42, https://doi.org/10.1016/j.dsr2. 2017.04.007.

Fodrie F.J., and K.L. Heck Jr. 2011. Response of coastal fishes to the Gulf of Mexico oil disaster. PLoS ONE 6:e21609, https://doi.org/10.1371/journal. pone.0021609.

Fodrie, F.J., K.W. Able, F. Galvez, K.L. Heck Jr., O.P. Jensen, P.C. López-Duarte, C.W. Martin, R.E. Turner, and A. Whitehead. 2014. Integrating organismal and population responses of estuarine fishes in Macondo spill research. BioScience 64(9):778-788, https://doi.org/10.1093/ biosci/biu123.

Grabowski, J.H., S.P. Powers, H. Roman, and S. Rouhani. 2017. Potential impacts of the 2010 Deepwater Horizon oil spill on subtidal oysters in the Gulf of Mexico. Marine Ecology Progress Series 576:163-174, https://doi.org/10.3354/ meps12208.

Grey, E.K., S.C. Chiasson, H.G. Williams, V.J. Troeger, and C.M. Taylor, 2015. Evaluation of blue crab, Callinectes sapidus, megalopal settlement and condition during the Deepwater Horizon oil spill. PLoS ONE 10(8):e0135791, https://doi.org/10.1371/ journal.pone.0135791.

Houghton, J.P., D.C. Lees, and T.A. Ebert. 1991. Evaluation of the Condition of Intertidal and Shallow Subtidal Biota in Prince William Sound Following the Exxon Valdez Oil Spill and Subsequent Shoreline Treatment. NOAA Report No. HMRB 91-1, vol. 1

Jensen, O.P., C.W. Martin, K.L. Oken, F.J. Fodrie, P.C. López-Duarte, K.W. Able, and B.J. Roberts. 2019. Simultaneous estimation of dispersal and survival of the gulf killifish Fundulus grandis from a batch-tagging experiment. Marine Ecology Progress Series 624:183-194, https://doi.org/ 10.3354/meps13040.

Kuhl, A.J., J.A. Nyman, M.D. Kaller, and C.C. Green 2013. Dispersant and salinity effects on weathering and acute toxicity of South Louisiana 
crude oil. Environmental Toxicology and Chemistry 32:2,611-2,620, https://doi.org/10.1002/ etc. 2346 .

Lane, S.M., C.R. Smith, J. Mitchell, B.C. Balmer, K.P. Barry, T. McDonald, C.S. Mori, P.E. Rosel, T.K. Rowles, T.R. Speakman, and others. 2015. Reproductive outcome and survival of common bottlenose dolphins sampled in Barataria Bay, Louisiana, USA, following the Deepwater Horizon oil spill. Proceedings of the Royal Society B: Biological Sciences 282(1818):20151944, https://doi.org/10.1098/rspb.2015.1944.

Lindeberg, M.R., J. Maselko, R.A. Heintz, C.J. Fugate, and L. Holland. 2018. Conditions of persistent oil on beaches in Prince William Sound 26 years after the Exxon Valdez spill. Deep Sea Research Part // 147:9-19, https://doi.org/10.1016/ j.dsr2.2017.07.011.

Martin, C.W. 2017. Avoidance of oil contaminated sediments by estuarine fishes. Marine Ecology Progress Series 576:125-134, https://doi.org/ 10.3354/meps12084.

McCann, M.J., K.W. Able, R.R. Christian, F.J. Fodrie, O.P. Jensen, J.J. Johnson, P.C. López-Duarte, C.W. Martin, J.A. Olin, M.J. Polito, and B.J. Roberts. 2017. Key taxa in food web responses to stressors: The Deepwater Horizon oil spill. Frontiers in Ecology and the Environment 15(3):142-149, https://doi.org/10.1002/fee.1474.

Mendelssohn, I.A., G.L. Anderson, D.A. Baltz, R.H. Caffey, J.W. Fleeger, S.B. Joye, Q. Lin, E. Maltby, E.B. Overton, and L.P. Rozas. 2012. Oil impacts on coastal wetlands: Implications for the Mississippi River Delta ecosystem after the Deepwater Horizon oil spill. BioScience 62(6):562-574, https://doi.org/ 10.1525/bio.2012.62.6.7

Michel, J., E.H. Owens, S.A. Zengel, A. Graham, Z. Nixon, T. Allard, W. Holton, P.D. Reimer, A. Lamarche, M. White, and others. 2013. Extent and degree of shoreline oiling: Deepwater Horizon oil spill, Gulf of Mexico, USA. PLoS ONE 8(6), https://doi.org/10.1371/journal.pone.0065087.

Michel, J., and N. Rutherford. 2014. Impacts, recovery rates, and treatment options for spilled oil in marshes. Marine Pollution Bulletin 82:19-25, https://doi.org/10.1016/j.marpolbul.2014.03.030.

Moody, R.M., J. Cebrian, and K.L. Heck Jr. 2013. Interannual recruitment dynamics for resident and transient marsh species: Evidence for a lack of impact by the Macondo oil spill. PLoS ONE 8:e58376), https://doi.org/10.1371 journal.pone.0058376.

NOAA (National Oceanic and Atmospheric Administration). 2015. NOAA RESTORE Act Science Program - Science Plan, https:// restoreactscienceprogram.noaa.gov/about/ science-plan.

NRC (National Research Council). 2014. The Gulf Research Program: A Strategic Vision. The National Academies Press, Washington, DC, 75 pp., https://doi.org/10.17226/18962.

Nixon, Z., S. Zengel, M. Baker, M. Steinhoff, G. Fricano, S. Rouhani, and J. Michel. 2016. Shoreline oiling from the Deepwater Horizon oil spill. Marine Pollution Bulletin 107:170-178, https://doi.org/ 10.1016/j.marpolbul.2016.04.003.

Nixon, Z., and J. Michel. 2018. A review of the distribution and quantity of lingering subsurface oil from the Exxon Valdez oil spill. Deep Sea Research Part // 147:20-26, https://doi.org/10.1016/j. dsr2.2017.07.009.

Patterson, W.F. III, D.J. Hollander, C.H. Jagoe, M.O. James, S.A. Murawski, I.C. Romero, and J.H. Tarnecki. 2015. Reef fishes and the Deepwater Horizon oil spill: Chronic effects and evidence of system resiliency. Paper presented at the 2015 Gulf of Mexico Oil Spill and Ecosystem Science Conference, February 16-19, 2015, Houston, TX.

Peterson, C.H., S.D. Rice, J.W. Short, D. Esler, J.L. Bodkin, B.E. Ballachey, and D.B. Irons. 2003. Long-term ecosystem response to the Exxon Valdez oil spill. Science 302:2,082-2,086, https://doi.org/10.1126/science.1084282.

Powers, S.P., S. Rouhani, M.C. Baker, H. Roman, J.H. Grabowski, S.B. Scyphers, J.M. Willis, and M.W. Hester. 2017a. Ecosystem services lost when facilitation between two ecosystem engineers is compromised by oil. Marine Ecology Progress Series 576:189-202, https://doi.org/10.3354/ meps12201.

Powers, S.P., J. Grabowski, H. Roman, A. Geggel, S. Rouhani, J. Oehrig, and M.C. Baker. 2017b. Consequences of large-scale salinity alteration during the Deepwater Horizon Oil spill on subtidal oyster populations. Marine Ecology Progress Series 576:175-187, https://doi.org/10.3354/ meps12147.

Schaefer, J., N. Frazier, and J. Barr. 2016. Dynamics of near-coastal fish assemblages following the Deepwater Horizon oil spill in the northern Gulf of Mexico. Transactions of the American Fisheries Society 145(1):108-119, https://doi.org/10.1080/ 00028487.2015 .1111253$.

Schrandt, M.C., S.P. Powers, S. Rikard, W. Thongda, and E. Peatman. 2018. Short-term low salinity mitigates effects of oil and dispersant on juvenile eastern oysters: A laboratory experiment with implications for oil spill response activities. PLoS ONE 13:e0203485, https://doi.org/10.1371/ journal.pone.0203485.

Short, J.W., H.J. Geiger, J.C. Haney, C.M. Voss, M.L. Vozzo, V. Guillory, and C.H. Peterson. 2017. Anomalously high recruitment of the 2010 Gulf menhaden (Brevoortia patronus) year class: Evidence of indirect effects from the Deepwater Horizon blowout in the Gulf of Mexico. Archives of Environmental Contamination and Toxicology 73:76-92, https://doi.org/10.1007/ s00244-017-0374-0.

Soto, L.A., A.V. Botello, S. Licea-Durán, M.L. LizarragaPartida, and A. Yáñez-Arancibia. 2014. The environmental legacy of the Ixtoc-1 oil spill in Campeche Sound, southwestern Gulf of Mexico. Frontiers in Marine Science 1:57, https://doi.org/10.3389. fmars.2014.00057.

van Der Ham, J.L., and K. De Mutsert. 2014 Abundance and size of gulf shrimp in Louisiana's coastal estuaries following the Deepwater Horizon oil spill. PLOS ONE 9(10), https://doi.org/10.1371/ journal.pone.0108884.

Whitehead, A., B. Dubanksy, C. Bodinier, T.I. Garcia, S. Miles, C. Pilley, V. Raghunathan, J.L. Roach, N. Walker, R.B. Walter, and others. 2012. Genomic and physiological footprint of the Deepwater Horizon oil spill on resident marsh fishes. Proceedings of the National Academy of Sciences of the United States of America 109:20,298-20,302, https://doi.org/ 10.1073/pnas.1109545108.

Zengel, S., B.M. Bernik, N. Rutherford, Z. Nixon, and J. Michel. 2015. Heavily oiled salt marsh following the Deepwater Horizon oil spill: Ecological comparisons of shoreline cleanup treatments and recovery. PLoS ONE 10(7):e0132324, https://doi.org/ 10.1371/journal.pone.0132324.

\section{ACKNOWLEDCMENTS}

This research was made possible in part by funding from the Gulf of Mexico Research Initiative. This project was paid for in part with federal funding from the Department of the Treasury through the Louisiana Coastal Protection and Restoration Authority's Center of Excellence Research Grants Program and the
Mississippi Department of Environmental Quality's Center of Excellence Research Grants Program under the Resources and Ecosystems Sustainability, Tourist Opportunities, and Revived Economies of the Gulf Coast States Act of 2012 (RESTORE Act). The statements, findings, conclusions, and recommendations are those of the authors and do not necessarily reflect the views of the Department of the Treasury, the Coastal Protection Restoration Authority, or the Mississippi Department of Environmental Quality. The Florida Centers of Excellence Grants Program is funded from the Gulf Coast Restoration Trust Fund, established in the Department of the Treasury under the RESTORE Act.

\section{AUTHORS}

Denis A. Wiesenburg (denis.wiesenburg@usm.edu) is Professor of Marine Science, The University of Southern Mississippi, Hattiesburg, MS, USA. Bob Shipp is Professor Emeritus, University of South Alabama, Dauphin Island Sea Lab, Dauphin Island, AL, USA. F. Joel Fodrie is Associate Professor, Institute of Marine Sciences, University of North Carolina at Chapel Hill, Morehead City, NC, USA. Sean Powers is Chair and Professor of Marine Sciences, University of South Alabama, Dauphin Island Sea Lab, Dauphin Island, AL, USA. Julien Lartigue is Director, NOAA's RESTORE Science Program, Stennis Space Center, MS, USA. Kelly M. Darnell is Assistant Research Professor, The University of Southern Mississippi, and Director, Mississippi Based RESTORE Act Center of Excellence, Ocean Springs, MS, USA. Melissa M. Baustian is Coastal Ecologist, The Water Institute of the Gulf, and Director, RESTORE Act Center of Excellence for Louisiana, Baton Rouge, LA, USA. Cam Ngo is Assistant Director, Florida Institute of Oceanography, and Interim Program Director, Florida RESTORE Act Centers of Excellence Program, St. Petersburg, FL, USA. John F. Valentine is Executive Director, Dauphin Island Sea Lab, and Director, Alabama Center of Excellence, Dauphin Island, AL, USA. Kateryna Wowk is Senior Research Scientist, Harte Research Institute for Gulf of Mexico Studies, and Director, RESTORE Act Texas OneGulf Center of Excellence, Corpus Christi, TX, USA.

\section{ARTICLE CITATION}

Wiesenburg, D.A., B. Shipp, F.J. Fodrie, S. Powers, J. Lartigue, K.M. Darnell, M.M. Baustian, C. Ngo, J.F. Valentine, and K. Wowk. 2021. Prospects for Gulf of Mexico environmental recovery and restoration. Oceanography 34(1):164-173, https://doi.org/10.5670/ oceanog.2021.124.

\section{COPYRIGHT \& USAGE}

This is an open access article made available under the terms of the Creative Commons Attribution 4.0 International License (https://creativecommons.org/ licenses/by/4.0/), which permits use, sharing, adaptation, distribution, and reproduction in any medium or format as long as users cite the materials appropriately, provide a link to the Creative Commons license, and indicate the changes that were made to the original content. 